\title{
Hiponatreminin Nadir Bir Sebebi: Sefaperazon-Sulbactam
}

A Rare Reason of Hyponatremia: Cefaperazone-Sulbactam

\author{
Memnune Sena ULU', Fatih KURBAN ${ }^{2}$, Erhan BOZKURT², Suat AKGÜR², Seref YUKSEL ${ }^{1}$ \\ ${ }^{1}$ Afyon Kocatepe Üniversitesi Tıp Fakültesi, Nefroloji BD, Afyonkarahisar, \\ ${ }^{2}$ Afyon Kocatepe Üniversitesi Tıp Fakültesi, İç Hastalıkları AD, Afyonkarahisar
}

\begin{abstract}
öz
Hiponatremi , serum sodyum düzeyinin $136 \mathrm{mmol} / \mathrm{L}$ nin altında olması olarak tanımlanır. Hastanede yatan hastalarda en sık görülen elektrolit bozukluğudur. İlaçlar hiponatremi nedenlerinden biridir. Sefaperazon-sulbaktam, klinik pratikte sık kullanılan bir antibiyotiktir. Çeşitli yanetkileri bilinmekle beraber, hiponatremi çok nadir olarak görülür. Kliniğimizde takip ettiğimiz, Sefaperazon-Sulbaktam kullanımına bağlı gelişen hiponatremi olgusuyla, ilaç ilişkili hiponatremiye dikkat çekmeyi amaçladık. Açıklanamayan hiponatremi gelişen hastalarda, nadir de olsa, antibiyotik ilişkili hiponatremi akılda tutulmalıdır.
\end{abstract}

Anahtar Kelimeler: Hiponatremi; elektrolit bozuklukları; sefaperazon-sulbaktam.

\begin{abstract}
Hyponatremia is defined as serum sodium level is lower than $136 \mathrm{mmol} / \mathrm{L}$. It is the most common electrolyte disorder in hospitalized patients. Drug-induced hyponatraemia is one of the reasons. Cefoperazone-sulbactam is a commonly used antibiotic in clinical practice. Although its several side effects are known, hyponatremia is very rare. We aimed to draw attention to drug-associated hyponatraemia with a case developing hyponatremia due to use of Cefoperazone-sulbactam. Although it is rare; antibiotic associated hyponatremia should be kept in mind in patients developing unexplained hyponatremia.
\end{abstract}

Keywords: Hyponatremia; electrolyte disorders; cefoperazone-sulbactam. 


\section{GíRiş}

Hiponatremi, serum sodyum düzeyinin 136 $\mathrm{mmol} / \mathrm{L}$ nin altında olması olarak tanımlanır. Hastanede yatan hastalarda en sık görülen elektrolit bozukluğudur (1). Prevalansı, hastaların etyolojisine göre ve tanımlamada kullanılan $\mathrm{Na}+$ düzeyine göre değişkenlik gösterir (2).

Sınır olarak $135 \mathrm{mEq} / \mathrm{L}$ alındığında hastaların yaklaşık \% 15-20' sinde, $130 \mathrm{mEq} / \mathrm{L}^{\prime}$ nin altında \%1-4' ünde hiponatremi görülür (3). Hiponatreminin en sık nedenleri; Uygunsuz ADH sendromu, diüretikler, antidepresanlar ve antileptikler gibi ilaçlardır (4- 7). Bunların yanında, hiponatremi pratikte sık kullanılan yeni nesil antihipertansif ajanlar, antibiyotikler, proton pompa inhibitörleri gibi ilaçlar ile de ortaya çıkabilir $(8,9)$. Sefaperazon sulbaktam, klinik pratikte sık kullanılan bir antibiyotiktir ve yan etkileri çoğunlukla gözden kaçmaktadır. Biz de, kliniğimizde takip ettiğimiz, Sefaperazon-Sulbaktam kullanımına bağlı gelişen hiponatremi olgusuyla, ilaç ilişkili hiponatremiye dikkat çekmeyi amaçladık.

\section{OLGU SUNUMU}

Atmış bir yaşında araç içi trafik kazası nedeni ile Beyin Cerrahisi kliniği tarafından opere edilen erkek hasta, postoperatif 5.günde gelişen hiponatremi nedeni ile tarafımıza konsülte edildi. Özgeçmişinde önemli Yapılan ilk değerlendirmede TA:100/70 mmHg, ateş:36,7'C, nabız 72/ dk ve solunum sayısı $20 / d k$ idi. Fizik muayanede önemli bir bulgu yoktu. Hastanın övolemik olduğu gözlendi. Laboratuar bulgularında, Hb:12,6 g/dl, WBC: 15970/ mm3, plt:222.000 / mm3, glukoz 111 mg/dl , BUN: 20,64 mg/dl , kreatinin: $0.29 \mathrm{mg} / \mathrm{dl}$, total protein: $6.33 \mathrm{~g} / \mathrm{dl}$, albumin $3.52 \mathrm{~g} / \mathrm{dl}$, sodyum $119 \mathrm{mEq} / \mathrm{l}$, kalsiyum $7.82 \mathrm{mg} / \mathrm{dl}$, potasyum $4.18 \mathrm{mEq} / \mathrm{l}$, AST $32.7 \mathrm{U} / \mathrm{L}$, ALT 25.2 U/L olarak bulundu. Hasta övolemik hiponatremi olarak değerlendirildi. Sodyum açığı hesaplanan hastaya hipertonik (\%3) NaCL solüsyonu ile sodyum replasmanı önerildi. Yapılan uygun süre ve dozdaki sodyum replasmanına rağmen hastanın hiponatremisinde düzelme olmadı. Bunun üzerine hasta Beyin cerrahisi kliniğinden devir alındı. Övolemik Hiponatremi nedenleri arasında sıklıkla görülen Uygunsuz ADH sendromu, adrenal yetmezlik, tiazid diüretikleri, ilaçlar ve hipotroidizm araştırılmaya başlandı. Hastanın trafik kazası ve beyin travması öyküsü olması nedeniyle ön planda "Uygunsuz ADH sendromu" düşünüldü ancak klinik ve laboratuar bulguları, kan osmolaritesi, idrar dansitesi, idrar sodyum atılımı "Uygunsuz ADH sendromu" ile uyumlu saptanmadı. Tiroid fonksiyon testleri, ve serum kortizol düzeyi de normal sınırlarda olan hastada adrenal yetmezlik ve hipotroidizm ekarte edildi. İlaç ilişkili hiponatremiyi dışlamak için hastanın almakta olduğu tedavi değerlendirildi. Diüretik, antidepresan veya antileptik kullanımı olmayan hastanın tedavide hastada hiponatremi gelişmesinden 36 Saat önce hastane kökenli pnömoni tanısı ile balgamda Klebsiella Pnömonia üremesi ve antibiyogramda duyarlı olması nedeni ile Sefaperazon-sulbaktam $2 \mathrm{gr} / \mathrm{gün}\left(2^{*} 1 \mathrm{gr}\right.$ iv 12 saatte bir ) başlandığı görüldü. Hastanın almakta olduğu Sefaperazon-sulbaktam tedavisi kesilerek yerine Ciprofloksasin tedavisine geçildi. Hastaya Hipertonik (\%3) NaCL solüsyonu ile sodyum replasmanına devam edildi. Na+ değerleri normal sınırlara ulaşan ve daha sonra tedavi almaksızın $\mathrm{Na}+>135 \mathrm{mEq} / \mathrm{L}$ olarak seyreden hasta, rehabilitasyon programına devam edilmek üzere taburcu edildi.

\section{TARTIŞMA}

Sefaperazon-sulbaktam, yarı sentetik 3.kuşak sefalosporinler grubunda yer alan, gram pozitif ve gram negatif bakterilerin tedavisinde kullanılan geniş spektrumlu bir antibiyotiktir (10).

Sefaperazon sulbaktam tedavisinin iyi bilinen yan etklileri trombositopeni, nötropeni, gastrointestinal hemoraji, hemolitik anemi ve Steven Johson sendromudur (11). Daha önce bazı ilaçlara (diüretikler, antidepresanlar, antileptikler, bazı antihipertansif ajanlar, antibiyotikler, proton pompa inhibitörleri ) bağlı hiponatremi vakaları görülmüştür (5-9).

laçların bir kısmı ADH benzeri etki göstererek, bir kısmı ADH sekresyonunu arttırarak, bir kısmı ADH'nın renal yanıtını güçlendirerek, bir kısmı da renal perfüzyonu azaltarak ve prostoglandin sentezini inhibe ederek hiponatremiye yol açabilirler (12-14).

Bugüne kadar ilaca bağlı hiponatremi vakarlı sık olarak bildirilmekle birlikte, hiponatremi Se- 
faperazon- sulbaktam tedavisinin nadir bir nedeni olarak sadece 1 vakada bildirilmiştir (15). Biz hastamızda gördük ki, açıklanamayan hiponatremi gelişen hastalarda, nadir de olsa, antibiyotik ilişkili hiponatremi akılda tutulmalıdır. Böylece hastaya gereksiz ileri tetkik ve tedavi yapmaktan kaçınılarak hastaların da erken müdahale ile hastanede yatış süresi kısaltılıp, mortalite ve morbiditesi azaltılabilir.

\section{KAYNAKLAR}

1. Verbalis JG, Goldsmith SR, Greenberg A, et al.Diagnosis, evaluation, and treatment of hyponatremia: expert panel recommendations. Am J Med 2013;126(10 Suppl 1):S1-42.

2. Adrogué HJ, Madias NE. Hyponatremia. N Engl J Med 2000;342(21):1581-9.

3. Upadhyay A, Jaber BL, Madias NE. Incidence and prevalence of hyponatremia. Am J Med 2006;119(1):30-5.

4. Schrier RW, Berl T, Anderson RJ. Osmotic and nonosmotic control of vasopressin release. Am J Physiol 1979;236(4):321-32.

5. Abramow M, Cogan E. Clinical aspects and pathophysiology of diüretic hyponatremia. Adv Nephrol Necker Hosp 1984;13(1):128.

6. Luzecky $\mathrm{MH}$, Burman KD, Schultz ER. The syndrome of inappropriate secretion of antidiuretic hprmone associated with amitriptyline administration. South Med J 1974:67(4):4957.

7. Steinhoff BJ, Stoll KD, Stodieck SR, Paulus W. Hyponatremic coma under oxcarbazepine therapy. Epilesy Res 1992;11(1):6770 .

8. Liamis $G$, Milionis $H$, Elisaf $M$. Review of drug-induced hyponatremia. American Journal of Kidney Diseases 2008;52(1):144-53.

9. Robert WS(Editör). Böbrek ve elektrolit hastalıkları. In: Tomas B, Robert WS. Su metabolizma bozuklukları. 6ncı Baskı, Ankara: Güneş Tıp Kitabevi, 2005:1-54.

10. Williams JD. Beta-lactamase inhibition and in vitro activity of sulbactam and sulbactam/cefoperazone. Clin Infect Dis 1997;24(3):494-7.

11. Kumar AV, Rao NR. Cefoperazone induced gastrointestinal haemorrhage. J Assoc Physic India 1999;47(8):840-1.

12. Rault RM. Case report: hyponatremia associated with nonsteroidal antiinflammatory drugs. Am J Med Sci 1993;305(5):318-20.

13. Kirch C, Gachot B, Germann N, Blot F, Nitenberg G. Recurrent ifosfamide-induced hyponatraemia. Eur J Cancer 1997;33(14):2438-9.
14. Schwab M, Ruder H. Hyponatraemia and cerebral convulsion due to DDAVP administration in patients with enuresis nocturna or urine concentration testing. Eur J Pediatr 1997;156(8):668.

15. Mitra S, Basu S. Cefoperazone / sulbactam induced hyponatremia. Indian J Med Sci 2006;60(4):158-9. 